\title{
Analysis of Estramustine Binding Protein (EBP) in Rat Dorsal Prostate by means of High Pressure Liquid Chromatography
}

\author{
HideToshi YAMANAKA, Hisako YUASA, NoZOMU KOSAKU, \\ NASIR BASHIRELAHI* AND KEIZO SHIDA \\ Department of Urology, School of Medicine, Gunma University, Maebashi, 371 \\ *Department of Biochemistry, University of Maryland, Dental School, \\ Baltimore, MD., U.S.A., 21201
}

\begin{abstract}
High pressure liquid chromatography (HPLC, Toyo Soda TSK-GEL G3000 SW column) was used to analyse the properties of Estramustine binding protein (EBP) in the cytosol of rat dorsal prostate. There exist in the cytosol of rat dorsal prostate two binding components having a high affinity for Estramastine. When estimated by HPLC, the molecular weights of these Estramustine binding components are 45,000-50,000 and 25,000 30,000 daltons, respectively. The binding of ${ }^{3} \mathrm{H}$-Estramustine to a macromolecule with a molecular weight of $25,000-30,000$ is more heat labile than binding of ${ }^{3} \mathrm{H}$-Estramustine to a macromolocule with a molecular weight of 45,000-50,000. The present study also demonstrates that the HPLC method offers higher resolution, smaller sample size and faster analysis than other methods used in binding studies.
\end{abstract}

Estramustine binding protein (EBP or EMBP) was discovered in the course of the investigation of estramustine phosphate (Estracyt ${ }^{\circledR}$, estradiol 3N-Bis-(2-chloroethyl)-carbamate- $17 \beta$-phosphate), a drug used for the treatment of prostatic cancer (Høisaeter, 1977; Høisaeter et al., 1981; Yamanaka et al., 1981a; Yamanaka et al., 1981b; Forsgren et al., 1979a; 1979c). It has been already reported by several investigators that there exists a macromolecule in the cytosol of ventral prostate. The physiochemical properties of this protein, such as the molecular weight, sedimentation coefficient and amino acid composition etc., are similar to those of EBP. Liao et al. (1975) designated this protein as " $\alpha$-protein". Heyns et al. (1977, 1978) and Lea et al. (1979) named it "prostatic binding protein (PBP)" and "prostatein", respectively. Recently, Kirdani et al. (1981) have used high pressure liquid chromatography

Received July 16, 1982.
(HPLC) to measure EBP in rat ventral prostate. They reported that HPLC offered higher resolution, smaller sample size and faster analysis than sucrose density gradient. We have investigated some properties of EBP in the cytosol from dorsal prostate of rat by means of HPLC (Toyo Soda TSK-GEL G3000 SW column).

\section{Materials and Methods}

\section{Chemical and radiochemical compounds.}

${ }^{3} \mathrm{H}$-Estramustine $\left(\left(2,4,6,16,17-{ }^{3} \mathrm{H}(\mathrm{N})\right.\right.$-estradiol- $17 \beta$ $3 \mathrm{~N}$-Bis-(2-chloroethyl)carbamate : $155 \mathrm{Ci} / \mathrm{mmole}$ ), Estramustine and Estromastine (estrone-3N-Bis-(2chloroethyl)carbamate) were kindly supplied by $\mathrm{AB}$ Leo, Hälsingborg, Sweden, Trizma base, Trizma $\mathrm{HCl}$, DL-dithiothreitol, EDTA-disodium salt and activated charcoal were obtained from Sigma Chemical Co., the marker proteins Combithek and calibration protein II were obtained from Boehringer Mannheim, Dextran (mol. wt., 60,000) was purchased from Nakarai Chemical, Ltd and Scintillation cocktail (INSTA-GEL) was 
purchased from Packard Instrument Co., Inc., Downers Grove, IL..

\section{Animals.}

Male Sprague-Dawley strain rats, 8-10 weeks, were maintained on laboratory chow from Japan Clea Co. and water ad libitum. Animals were housed in metabolic cages in a temperature-controlled room under a 12 hours light-12 hours dark lighting schedule. Animals had orchiectomy via the scrotal route under ether anaesthesia 21 hours before sacrifice.

\section{Preparation of cytosol.}

The prostates of castrated rats were removed and immediately frozen in liquid nitrogen and stored at $-90^{\circ} \mathrm{C}$ until use. The frozen prostates were pulverized and homogenized in about 6 volumes of $10 \mathrm{~mm}$ Tris$\mathrm{HCl}$, (pH 7.2) $1 \mathrm{~mm}$ EDTA- $0.1 \mathrm{~mm}$ Dithiothreitol$10 \%$ glycerol (TEDG buffer), using a Polytron at maximum setting for 2 periods of 5 seconds with intervals of 55 seconds for cooling. The homogenate was centrifuged for $60 \mathrm{~min}$. at $123,400 \times \mathrm{g}$ in an Hitachi RP50-2 rotor and the supernatant (cytosol) was carefully removed. The protein concentration of cytosol was determined according to the method of Lowry et al. (1951) using BSA as a standard. All procedures for handling the tissue were performed on ice in a cold room.

\section{Preparation of "bound Estramustine" fraction.}

Cytosol sample (10 mg protein) was incubated with ${ }^{-3} \mathrm{H}$-Estramustine $\left(1 \times 10^{-8} \mathrm{M}\right)$ for 20 hours at $0^{\circ} \mathrm{C}$ in the absence or presence of a 100 fold excess of unlabelled Estramustine. Separately, $3 \mathrm{ml}$ of DCC suspension consisting of $0.5 \%$ charcoal- $0.005 \%$ Dextran in TEDG buffer was centrifuged for $15 \mathrm{~min}$. at $700 \times \mathrm{g}$. The incubated sample was added to the charcoal pellet and mixed vigorously and then centrifuged for 15 min. at $700 \times \mathrm{g}$. The supernatant (DCC treated cytosol) was used in the following experiment as "bound Estramustine" fraction.

\section{High pressure liquid chromatography (HPLC).}

$100 \mu \mathrm{l}$ of "bound Estramustine" fraction was injected into an HPLC column. HPLC was carried out at $4^{\circ} \mathrm{C}$ using a model HPLC-803A liquid chromatograph (Toyo Soda) connected to two TSK-GEL G3000 SW columns $(7.5 \times 600 \mathrm{~mm})$ with precolumn $(7.5 \times 75 \mathrm{~mm})$. The elution was performed at $1 \mathrm{ml}$ per minute using $0.075 \mathrm{M}$ phosphate buffer, $\mathrm{pH} 7.2$ and fractions $(0.5 \mathrm{ml})$ were collected with a 2112 Redirac fraction collector, LKB Inc. for the determination of radioactivity.

\section{Results}

\section{HPLC separation of Estramustine binding} protein $(E B P)$ in the cytosol of rat dorsal prostate.

The experiment was designed to investigate the presence of cytoplasmic binding proteins for Estramustine in rat dorsal prostate by means of HPLC. Fig. 1 shows the elution profiles of dorsal prostate incubated with $1 \times$ $10^{-8} \mathrm{M}{ }^{3} \mathrm{H}$-Estramustine. Four prominent protein peaks (peaks I, II, III and IV) were seen to have a retention time (Rt) of $33.4 \pm$ 0.10 min., $34.80 \pm 0.10$ min., $39.46 \pm 0.04 \mathrm{~min}$. and $41.36 \pm 0.04 \mathrm{~min}$., respectively. Two radioactive peaks were seen which corresponded to protein peaks with molecular weights of 45,000

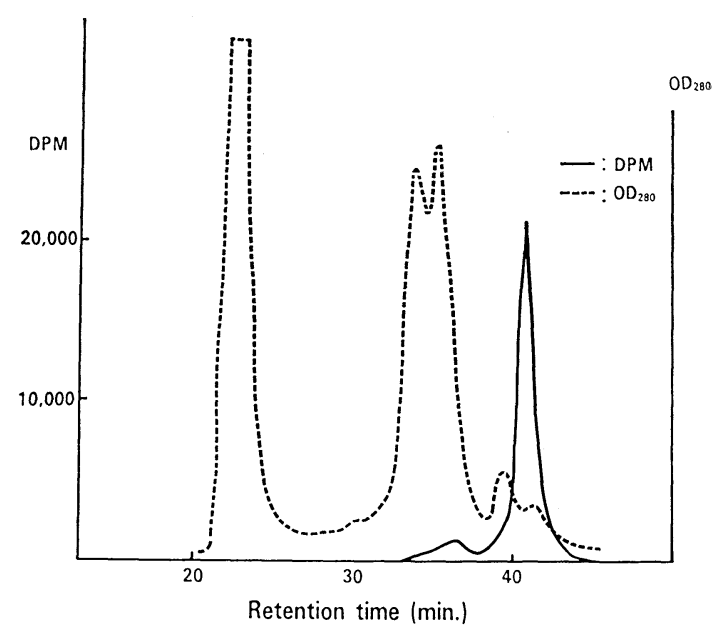

Fig. 1. A typical HPLC separation profile of EBP in the cytosol of rat dorsal prostate.

$100 \mu \mathrm{l}$ of bound Estramustine fraction (DCC treated cytosol) was injected into HPLC column. The elution conditions were as follows:

Apparatus : Toyo Soda HLC-803A

Column : TSK-GEL GSWP+G3000SW (7.5 $\mathrm{mm}$ ID, $600 \mathrm{~mm} \times 2$ )

Eluent : $\mathbf{0 . 0 7 5} \mathrm{M}$ phosphate buffer, $\mathrm{pH} \quad 7.2$

Pressure : $56 \mathrm{~kg} / \mathrm{cm}^{2}$

Flow rate $\quad: \quad 1.0 \mathrm{ml} / \mathrm{min}$

Sample concentration: $1 \mathrm{w} / \mathrm{v} \%$

Amount loaded: $100 \mu \mathrm{l}$

Dectector: UV $280 \mathrm{~nm}, 0.31-0.16$ (ABS)

Temperature: $4^{\circ} \mathrm{C}$ 
$-50,000$ and $25,000-30,000$, respectively. The relation time of each reference standard was as follows: Ferritin (Rt $26.60 \mathrm{~min}$.), Aldolase (Rt 30.50 min.), BSA (Rt 33.44 min.), Eggalbumin (Rt $36.20 \mathrm{~min}$.), Chymotrypsinogen (Rt 41.96 min.) and Cytochrome C (Rt 43.96 $\min$.).

2. Ligand specificity of Estramustine binding protein $(E B P)$.

Aliquots of cytosol prepared from rat dorsal prostate were incubated with ${ }^{3} \mathrm{H}$ Estramustine $\left(1 \times 10^{-8} \mathrm{M}\right)$ in the absence or presence of a 100 fold excess of the compounds tested. As shown in Fig. 2, addition of a 100 fold excess of $5 \alpha$-dihydrotestosterone and estradiol-17 $\beta$ did not lower the two radioactive peaks at all. On the other hand, when added in 100 fold excess, both Estramustine and Estromustine inhibited the binding of ${ }^{3} \mathrm{H}$-Estramustine to the macromolecules, especially to the macromolecule with a molecular weight of 25,000-30,000. These results indicate the presence of specific binding proteins for Estramustine in rat dorsal prostate cytosol.

\section{Effect of temperature on Estramustine/ protein complex.}

The binding rate between ${ }^{3} \mathrm{H}$-Estramustine and Estramustine binding components was studied at $0^{\circ} \mathrm{C}$ and $22^{\circ} \mathrm{C}$ by means of HPLC (Fig. 3).

At $22^{\circ} \mathrm{C}$, Estramustine specific binding to a macromolecule with a molecular weight of 25,000-30,000 showed a sharp maximum following 3 hours incubation. When incubated for 24 hours, the specific bound radioactivity decreased to $50 \%$ of the maximum bound radioactivity. At $0^{\circ} \mathrm{C}$, Estramustine specific binding with a macromolecule with a molecular weight of 25,000-30,000 after 24 hours incubation was increased to a level which was about 3 times the value after 3 hours incubation. At both $0^{\circ} \mathrm{C}$ and $22^{\circ} \mathrm{C}$, the binding rate of ${ }^{3} \mathrm{H}$-Estramustine to a macromolecele with a molecular weight of $45,000-50,000$ increased

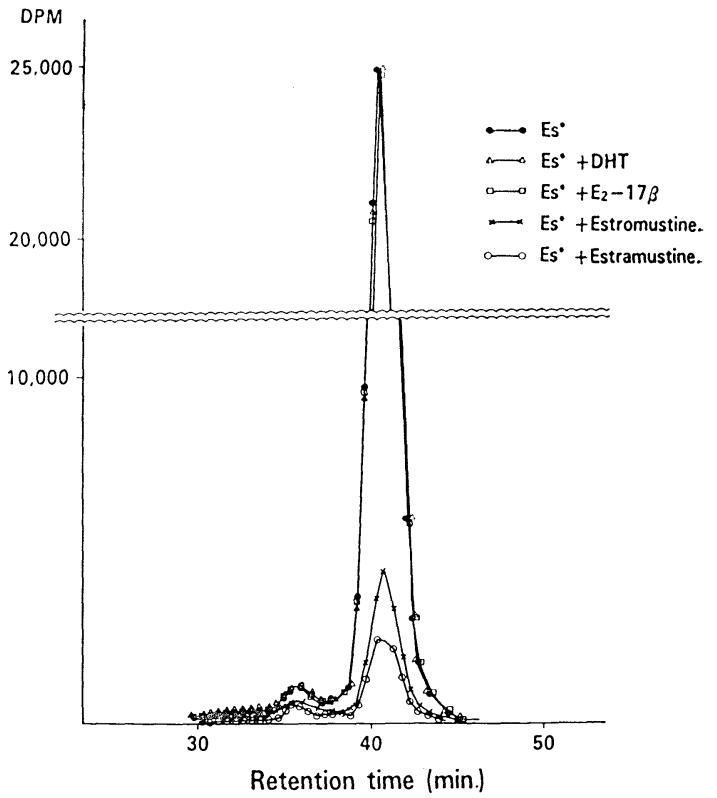

Fig. 2 Ligand specificity of EBP.

Aliquots of cytosol were incubated for 20 hours at $0^{\circ} \mathrm{C}$ with $1 \times 10^{-8} \mathrm{M}^{3} \mathrm{H}$-Estramustine in the absence (-) or presence of 100 fold excess of unlabelled DHT $(\triangle-\Delta)$, Estradiol-17 $\beta(\square-\square)$, Estromustine $(x-x)$ or Estramustine $(\bigcirc-\bigcirc)$. Free ligands were removed by dextran coated charcoal treatment at $0-4{ }^{\circ} \mathrm{C}$. Aliquots of DCC treated cytosol were injected into HPLC column. The elution conditions were the same as described in the legend to Fig. 1.

with the increasing incubation time. The effect of further incubation at different temperatures on the DCC-resistant Estramustine - protein complex formed at $0^{\circ} \mathrm{C}$ for 20 hours was studied (Fig. 4). When incubated at $22^{\circ} \mathrm{C}$ for 90 minutes following $0^{\circ} \mathrm{C}$ incubation for 20 hours, the second radioactive peak fell and the first radioactive peak rose, compared with Incubation at $0^{\circ} \mathrm{C}$ for 90 minutes following $0^{\circ} \mathrm{C}$ incubation for 20 hours. These results suggest that the complex of Estramustine and a macromolecule with a molecular weight of $25,000-30,000$ degrades after further incubation at $22^{\circ} \mathrm{C}$ and the free Estramustine binds to a macromolecule with a molecular weight of $45,000-50,000$. 

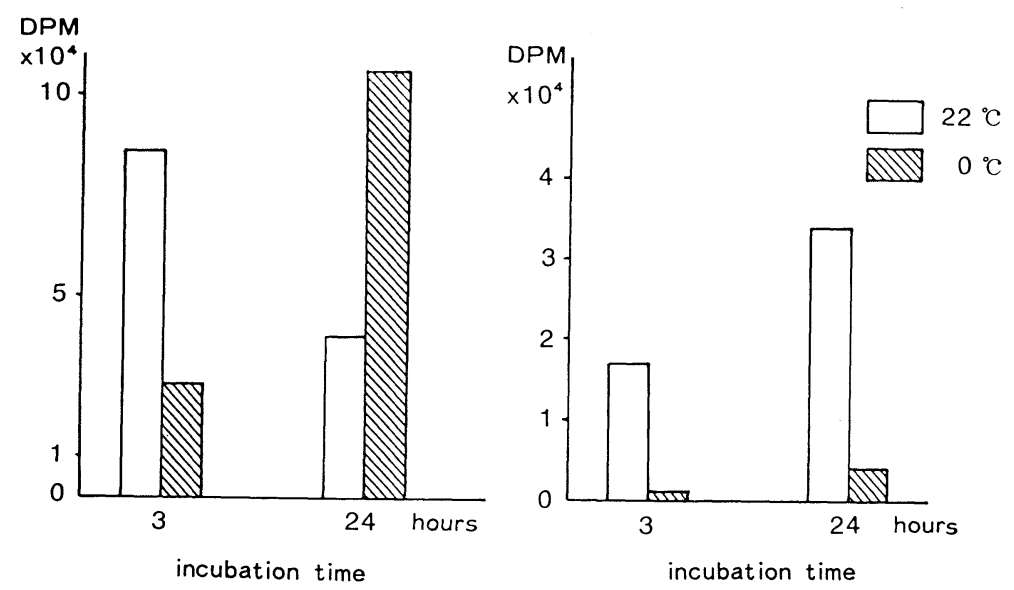

Fig. 3. Effect of temperature on the rate of association of specific Estramustine binding to macromolecules in the cytosol of rat dorsal prostate.

A). Specific binding of ${ }^{3} \mathrm{H}$-Estramustine to a macromolecule with a molecular weight of 25,000-30,000.

Aliquots of

incubation conditions (time and temperature) in the absence or presence of a 100 fold excess of unlabelled Estramustine. $100 \mu \mathrm{l}$ of bound Estramustine fraction (DCC treated cytosol) was injected into an HPLC column. The cumulative radioactivities of two radioactive peaks, which corresponded to protein peak II and protein peak IV respectively, were measured. Specific binding was determined by subtracting nonspecific binding (in the presence of a 100 fold excess of unlabelled Estramustine) from total binding (in the absence of unlabelled Estramustine).

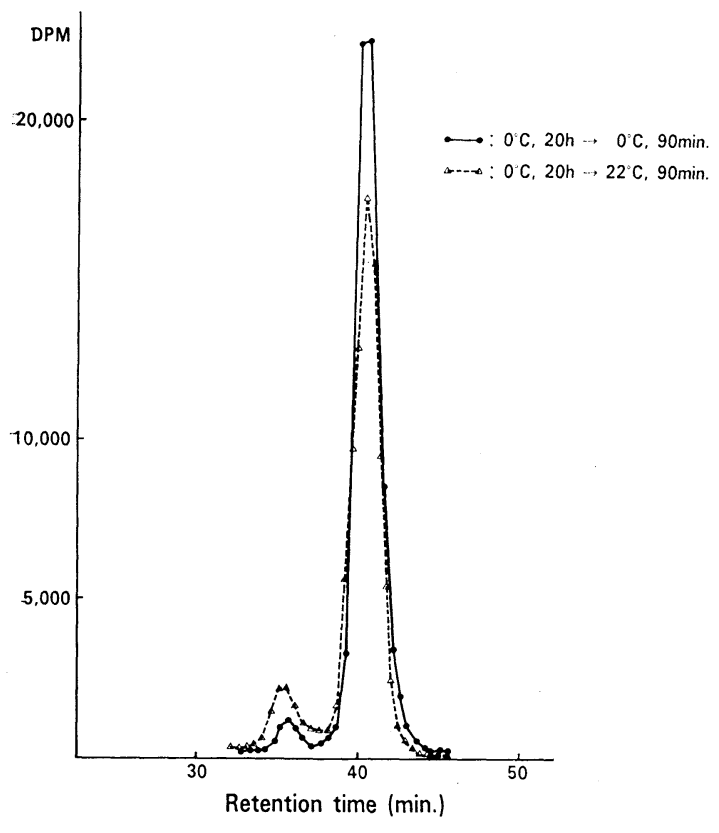

Fig. 4. The effect of further incubation at different temperatures on DCC resistant Estramustine protein complex formed at $0^{\circ} \mathrm{C}$ for 20 hours.

Aliquots of the cytosol sample were incubated with ${ }^{3} \mathrm{H}$-Estramustine $\left(1 \times 10^{-8} \mathrm{M}\right)$ for 20 hours at $0^{\circ} \mathrm{C}$. Free and loosely bound ligands were removed by dextran coated charcoal treatment. The DCC treated cytosols were further incubated at $0^{\circ} \mathrm{C}$ (-) or at $22^{\circ} \mathrm{C}(\Delta-\Delta)$ for 90 minutes. After further incubation, aliquots of $100 \mu 1$ were injected into HPLC. The elution conditions were the same as described in the legend to Fig. 1. 


\section{Discussion}

Rat prostate consists of the ventral, lateral, dorsal and anterior prostate. Each prostatic lobe has been reported to have a different nature and specificity of the secretion products. Rat ventral prostate secretes high amounts of citrate, spermine and spermidine (Price and Williams-Ashman, 1961) while the lateral prostate is the zinc-secreting portion of rat prostate (Gunn and Gould, 1957). We have already reported that the effect of estrogen on some enzyme activities in the dorsolateral prostate differed from that in the ventral prostate (Yamanaka et al., 1975).

Forsgren et al. (1979b) and Yamanaka et al. (1981b) have reported the existence of a protein that has a high affinity for Estramustine in rat ventral prostate. Forsgren et al. (1979a) isolated Estramustine binding protein (EBP) from rat ventral prostate and analyzed the amino acid composition and found it identical to that of prostatic binding protein of Heyns and De Moor (1977). It was demonstrated (Yamanaka et al., 1982) by means of HPLC that there existed two radioactive peaks of ${ }^{3} \mathrm{H}$-Estramustine in the cytosol of rat ventral prostate and the molecular weight of the main radioactive peak was 45,000 50,000 and that of the smaller peak was 25,000 -30,000. With HPLC Kirdani et al. (1981) also showed two radioactive peaks, which corresponded to two prominent protein peaks with molecular weights of 60,000 (main peak) and 32,000 daltons (smaller peak) in the cytosol of rat ventral prostate. The difference between the molecular weights of Estramustine binding components in their data and ours was presumed to be caused by the difference between the elution conditions, such as the kind of column and eluent. Heyns et al. (1978) reported that the molecular weight of prostatic binding protein, estimated by gel filtration, was 51,000 and this protein dissociated into two subunits. The molecular weight of the subunits was about 17,000 , when estimated by gel filtration in $6 \mathrm{M}$ guanidine hydrochloride.

It is of value to know whether EBP exists in other lobe as well as the ventral prostate. Using the HPLC technique, we have clearly demonstrated the presence of two binding proteins (mol. wt, 45,000 - 50,000 and 25,00030,000 , respectively) that have a high affinity for Estramustine in rat dorsal prostate. It is a very interesting phenomenon that in the cytosol of rat dorsal prostate the main radioactive peak corresponded to the protein peak with the molecular weight of $25,000-30,000$. Moreover, both Estramustine and Estromustine have a much higher inhibitory effect on the formation of Estramustine-macromolecule complex with a molecular weight of 25,000-30,000 than the Estramustine-macromolecule complex with a molecular weight of $45,000-50,000$. Furthermore, the binding of ${ }^{3} \mathrm{H}$-Estramustine to a macromolecule with a molecular weight of $25,000-30,000$ is more heat labile than the binding of ${ }^{3} \mathrm{H}$-Estramustine to a macromolecule with a molecular weight of 45,000-50,000. The relationship between these two Estramustine binding components in rat dorsal prostatic cytosol remains to be established. The participation of EBP in the intracellular recycling and the regulation of the steroid receptor complex requires investigation.

\section{Acknowledgments}

This work was supported in part by a grant from the Ministry of Education, Science and Culture, Japan, and a grant-in-aid for cancer research from the Ministry of Health and Welfare of Japan.

\section{References}

Forsgren, B., Bjørk, P., Carlstrom, K., Gustafsson, J. A., Pousette, A., and Högberg, B. (1979a). Purification and distribution of a major protein in the rat prostate that binds estramustine, a nitrogen mustard derivative of estradiol-17 $\beta$. Proc. Natl. Acad. Sci. U.S.A. 76, 3149-3156.

Forsgren, B., Gustafsson, J. A., Pousette, A., and 
Högberg, B. (1979b). Binding characteristics of a major protein in rat ventral prostate cytosol that interacts with estramsutine, a nitrogen mustard derivative of $17 \beta$-estradiol. Cancer Res. 39, 51555164.

Gunn, S. A. and Gould, T. C. (1957). A correlative anatomical and functional study of the dorsolateral prostate of the rat. Anat. Rec. 128, 41-53.

Heyns, W. and De Moor, P. (1977). Prostatic binding protein: a steroid binding protein secreted by rat prostate. Eur. J. Biochem. 78, 221-230.

Heyns, W., Peeters, B., Mous, J., Rombauts, W., and De Moor, P. (1978). Purification and characterization of prostatic binding protein and its subunits. Eur. J. Biochem. 89, 181-186.

Høisaeter, P. A. (1977). In vitro binding of tritiated hormone-cytostatic complexes in the cytosol of various rat tissues and the incorporation of these complexes into nuclei. Scan. J. Urol. Nephrol. 11, 135-141.

Høisaeter, P. A., Kadohama, N., Corrales, J. J., Karr, J. P., Murphy, G. P., and Sandberg, A. A. (1981). Characterization of androgen receptor and estramustine binding protein of rat ventral prostatic tissue in organ culture. J. Steroid Biochem. 14, 251-260.

Kirdani, R. Y., Corrales, J. J., Høisaeter, P. A., Karr, J. P., Murphy, G. P., and Sandberg, A. A. (1981). Estramustine binding in rat, baboon and human prostate measured by high pressure liquid chromatography. Steroids 37, 471-484.

Lowry, O. H., Rosebrough, N. J., Farr, A. F., and Radall, R. J. (1951). Protein measurement with the Folin phenol reagent. J. Biol. Chem. 193, 265275.

Lea, O. A., Petrusz, P., and French, F. S. (1979). Pro- statein: a major secretory protein of the rat ventral prostate. J. Biol. Chem. 254, 6196-6202.

Liao, S., Tymoczko, J. L., Castaneda, E., and Liand, T. (1975). Androgen receptors and androgen dependent initiation of protein synthesis in the prostate. Vitam. Horm. 33, 297-318.

Pousette, A., Bjørk, P., Carlstrom, K., Forsgren, B., Gustafsson, J. A., and Högberg, B. (1980). On the presence of "prostatic secretion protein" in different species. Acta Chem. Scand. 334, 155-156.

Price, D., and Williams-Ashman, H. G. (1961). The accessory reproductive glands of mammals. in Sex and Internal Secretions (Young, W. C., ed.). pp. 331-488. The Williams and Wilkins Co., Baltimore, MD.

Yamanaka, H., Shimazaki, J., Imai, K., Sugiyama, Y., and Shida, K. (1975). Effect of estrogen administration on activities of testosterone $5 \alpha$-reductase, alkaline phosphatase and arginase in the ventral and dorsolateral prostates of rat. Endocrinol. Japan. 22, 297-302.

Yamanaka, H., Kitaura, K., Imai, K., Yuasa, H., Nakai, K., Matsumura, Y., Uehara, H., and Shida, K. (1981a). In vivo studies of ${ }^{3} \mathrm{H}$-estramustine in castrated male rat. Acta Urol. Jpn. 27, 243-250.

Yamanaka, H., Imai, K., Yuasa, H., and Shida, K. (1981b). Mechanism of retention of estramustine in the rat prostate and results of a clinical trial of Estracyt in Japan. The prostate, Suppl. 1, 95-102. Yamanaka, H., Yuasa, H., Koya, A., Nakái, K., Uehara, H., Kosaku, N., Matsumura, Y., and Shida, K. (1982). Some properties of EMBP in rat prostates. (in Japanese). Clin. Endocrinol. 30, 11131117. 